\title{
Çingenelerin Ötekileştirilmesi Bağlamında Korkoro Filmi Üzerine Dekonstrüktif Bir Okuma
}

\author{
Meltem Kaya* \\ Arda Kaya*
}

Özet

Kendini tanımlama biçimi olarak görülen öteki, tarihsel bağlamda bakıldiğında farkh olanı anlatma biçimi olarak kullanılmaktadır. Öteki olana bakış, stereotip, damgalama, ön yargı, ötekileştirme ve dışlama şeklinde gerçekleşmektedir. Insanlik tarihinden bu yana pek çok ötekileştirme türü ortaya çıkmış, bireyler kendilerini tanımlamak için "öteki/ötekiler" belirlemişlerdir. Çalışmada etnosentrik ötekileştirmeye maruz kalan Çingeneler ele alınmıştır. Göçebe bir topluluk olarak yaşayan Çingeneler, gittikleri her ülkede ötekileştirilmiş, pek çok dışlayıcı tanımlama ile karşı karşıya kalmışlardır. $\mathrm{Bu}$ çalışmanın amacı, Çingenelerin yaşamış olduğu ötekileştirme problemlerine tarihsel bir izlek çerçevesinde incelemek ve bir sanat dalı olan sinemanın, Çingeneler gibi dışlanmış kişilere daha fazla eğilmesi gerektiğini vurgulamaktır. Çalışmanın amacına yönelik ise yönetmenliğini Tony Gatlif'in yapmış olduğu Korkoro (Özgürlük, Tony Gatlif, 2010) filmi ele alınmıştır. Yönetmen, filmde gerçek bir Çingene ailesinin yaşamış olduğu travmatik olayları anlatmaktadır. Korkoro filmi, çalışma ile doğrudan örtüştüğ̈̈ için seçilmiştir. Film çözümlemesi Derrida'nın dekonstrüktifokuması üzerinden yapılmıştır. Okuma gerçekleştirilirken New Mexico Literacy Project'in belirlemiş olduğu 5 soru üzerinden film analiz edilmiştir. Batıl filmlerin hepsi tek tek incelenmese de genel bağlamda bakıldığında, Çingene kökenli olmayan yönetmenlerin Çingenelerin ötekileştirilme sorununa çok fazla eğilmedikleri açık bir şekilde görülmektedir. Bu nedenle gerek literatür çalışmasında, gerekse film incelemesinde Batılı yönetmenlerin Çingenelerin ötekileştirilmesi konusunda daha fazla film yapılması gerektiği sonucuna varılmıştır.

Anahtar Sözcükler: Öteki, Ötekileştirme, Çingene, Korkoro, Film Analizi, Dekonstrüktif Okuma

ORCID ID : https:/ / orcid.org/ 0000-0003-3339-1231 - 0000-0002-1768-0810

E-mail : mltmkaya36@gmail.com - kaya.arda6@gmail.com

DOI: $10.31122 /$ Sinefilozofi.625976

Geliș Tarihi - Recieved: 12.09.2019

Kabul Tarihi - Accepted: 01.12.2019 


\title{
A Deconstructive Reading on the Korkoro Movie in the Context of the Otherization of Gypsies
}

\author{
Meltem Kaya* \\ Arda Kaya*
}

\begin{abstract}
The other, which is seen as a form of self-definition, is used as a way of telling what is different in historical context. The view of the other is stereotype, stigmatization, prejudice, marginalization and exclusion. Since the history of humanity, many other types of othering have emerged and individuals have identified "other /others" to identify themselves. In this study, Gypsies subjected to ethnocentric marginalization are discussed. The Gypsies, who live as a nomadic community, have been marginalized in every country they went to, and faced many exclusionary definitions. The aim of this study is to examine the problems of Gypsies' marginalization in the context of a historical perspective and to emphasize that cinema, which is a branch of art, should focus more on the excluded people like Gypsies. For the purpose of the study, the film Korkoro Tony directed by Tony Gatlif is discussed. The film tells the traumatic events of a real Gypsy family. The film Korkoro was chosen for its direct overlap with the work. The film analysis was based on the deconstructive reading of Derrida. During the reading, the film was analyzed on 5 questions determined by New Mexico Literacy Project. Although not all Western films are examined individually, it is clear that in general terms, non-Gypsy directors do not pay much attention to the problem of Gypsies' marginalization. For this reason, both literature review and film analysis concluded that Western directors should make more films about the marginalization of Gypsies.
\end{abstract}

Key Words: Other, Othering, Gypsy, Korkoro, Film Analysis, Deconstructive Reading

ORCID ID : https:/ / orcid.org/ 0000-0003-3339-1231 - 0000-0002-1768-0810

E-mail :mltmkaya36@gmail.com - kaya.arda6@gmail.com

DOI: 10.31122/Sinefilozofi.625976

Geliş Tarihi - Recieved: 12.09.2019

Kabul Tarihi - Accepted: 01.12.2019 


\section{Giriş}

Batı metafizik düşünce geleneğine dayanan "ben" ve "öteki" ayrımı, bireylerin, grupların kendini tanımlama biçimi olarak ortaya çıkmıştır. Logos merkeze Batı konulurken, merkezin dişında kalanlar periferiye itilerek ötekileştirilmiştir.

Tarihsel bağlamda pek çok ötekileştirme türü ortaya çıkmış, çalışmada etnosentrik ötekileştirme bağlamında Çingenelerin ötekileştirilmesi ele alınmıştır. "Avrupa' nın zencileri" olarak adlandırılan Çingeneler (Blum-Reid, 2005, 2), göçebe bir yaşam tarzı benimseyerek gittikleri pek çok ülkede ötekileştirilmeye maruz kaldıkları görülmüştür. Çingenelere yönelik son yıllarda "ötekileştirme" olarak nitelendirilebilecek haberlerden birkaçına bakarak, Çingenelerin ötekileştirmeye maruz kaldıkları mevcut örnekler üzerinden de görülebilir.

Örneğin; "Macar Bakan sığınmacıların entegrasyonunu Çingenelere benzetti" (AA, 2018) başlıklı haberde Bakan’ın ötekileştirme ifadesi olarak "Çingene" sözcüğünü kullandığ1 görülmektedir. Bir diğer örnek olarak ise "İbrahimovic' in heykeline ırkçı saldırı" (CNNTURK, 2019) başlıklı haber verilebilir. Haberin içeriğinde saldırganların, heykelin bulunduğu yere eski Yugoslavya'da kullanılan “Cigani dö” (Çingene'ye ölüm) şeklinde ırkçı slogan yazdığı belirtilmiştir. Bu sözcük de yine Çingenelere yönelik ırkçılığa varacak boyuttaki ötekileştirmenin bir ifadesi olarak okunmaktadır. Her iki haberde de yer alan söylem ve pratikler incelendiğinde, Çingenelere yönelik ötekileştirme davranışının günümüzde de devam ettiği açık bir şekilde görülmektedir.

Çalışmada öncelikle kendini tanımlama biçimi olarak "öteki" ve "ötekileştirme" kavramlarına bakılarak, kuramsal bir altyapı çizilmiştir. Daha sonra ise etnosentrik ötekileştirme bağlamında Çingenelerin ötekileştirilmesi tarihsel izlek üzerinden aktarılmıştır. Çingenelerin ötekileştirilmesinin Korkoro (Özgürlük, Tony Gatlif, 2010) filmi üzerinden incelendiği bu makalede, "Çingene" sözcüğü bilinçli olarak kullanılmıştır. "Roman" sözcüğü, "Çingene" sözcüğünün getirmiş olduğu olumsuz çağrışımdan ötürü kullanılmaktadır. Bu durum da ötekileştirici bir ifade olarak yorumlandığından çalışma boyunca "Çingene" kelimesi tercih edilmiştir.

Araştırmanın amacı, bir sanat olan sinemanın "öteki”, "arkaik”, "yabancı" olarak görülen bireyler ya da grupların yaşamış oldukları dışlanmışlığa daha fazla yer verilerek, bireyleri bilinçlendirmesi gerektiğini göstermektedir. Bu amaçtan hareketle, geçmişten günümüze periferiye itilen Çingenelerin yaşam tarzları, özgürlüklerinin elinden alınması ve yaşamış oldukları dışlanmışlıklar, çalışma boyunca ele alınmıştır. Etnosentrik ötekileştirmeye maruz kalan Çingenelerin, yaşamış oldukları ayrımcılığı en iyi anlatan filmlerden biri olan Korkoro, çalışmanın örneklemini oluşturmaktadır. Kökeni Çingene olan Fransız yönetmen Tony Gatlif'in çekmiş olduğu film, "ben/biz" olarak görülen Batılı yönetmenlere de yön vermesi amacıyla seçilmiştir.

Korkoro filmi, hem söylemsel, hem de görüntüsel olarak derin anlamlar ifade etmektedir. Bu nedenle film Derrida' nın dekonstrüktif (yapısöküm) okuması ileçözümlenmiştir. Söylemler, mekanlar, renkler, sesler tek tek incelenerekaltmetinler bulunmuş, Çingenelerin ötekileştirmeye uğradığı sahneler gösterilmeye çalışılmıştır. Dekonstrüktif okuma gerçekleştirilirken, New Mexico Literacy Project' in (Nkana, 2010) belirlemiş olduğu beş sorunun cevapları ile çalışma son bulmuştur.

\section{Ben'i Tanımlama Biçimi Olarak Öteki'ye Kuramsal Bakış}

Ötekileştirme ve ötekileştirme türlerini anlayabilmek için, öteki kavramının kuramsal okumasını yapmak, önem arz etmektedir. Öteki terimi açıklanırken, Batı metafizik düşünce 
geleneği olan düalist epistemoloji üzerinden tanımlama gerçekleştirilmiş ve bu noktada Hegel'e başvurulmuştur.

"Hegel tez, antitez ve sentez olarak formülleştirdiği diyalektikle varlıklar arası karşılıklı ilişki, zıtlıklar biçimindeki etkileşim bir biçimde birleşmeye, yani uzlaşmaya dönüşmektedir" (Güngör, 2016, 24). Bir diğer deyişle bireyler, kendilerini antitezi, yani ötekisi üzerinden tanımlamaktadır.

Hegel, Tinin Görüngübilimi kitabında, özbilincin kendi içinde olduğunu, özbilincin ilk olarak kendisini yitirdiğini ve kendinden başka somut bir öz olarak bulduğunu belirtmektedir. Öteki, bağımsız özü ortadan kaldırarak, kendisinden başka bir öz yaratır. (1986, 124-125) Yani ben, özbilincinden bağımsız olarak öteki ile karşılaşır ve kendisini yeniden tamamlar. Bu bağlamda Hegel'in antitezi, ben' in kendisini öteki üzerinden tanımladı̆̆ı yeni bir ben' dir. Bu diyalektik, toplumların kendilerini tanımladığı noktada da geçerlidir.

Öteki kavramına etimolojik bir çerçeveden bakılırsa, 4.yüzyıldan 7. ve 6. yüzyıla kadar Greklerin "yabancı" için kullandıkları bir terimdir. Bu esnada barbar terimi de öteki söylemi içinde alt-insanlık fikrini geliştirme yolunda kullanılmıştır. 12. Yüzyıldan, 18. yüzyıla kadar Hristiyan olmayanlar ve vahşi davrananlar için kullanılırken; 18. yüzyıla gelindiğinde, Rönesans'ta aydınlanmamış olanlar için kullanılmıştır. 20. yüzyılda ise Avrupa ve Amerika'nın "cahil", "geleneksel" ve "kendilerinden daha az akıllı" gördükleri üçüncü dünya ülkelerinin temsilleri olarak öteki kavramı kullanılmıştır. Günümüzde Batı dünyasında öteki teriminin kullanımına bakılırsa, Avrupa idealini tehdit eden Japonlar, Müslümanlar ve yoksullar, ötekiler olarak görülmektedir. (Sözen, 1999, 24-25) Görüldüğü gibi geçmişten, günümüze öteki terimi pek çok değişim geçirmiş olsa da yüklenen anlam hep olumsuz göndermeler içermektedir.

Romalı olmayanları belirten bir başka öteki kelimesi de bugün dahi bu ötekilik mirasını sürdüren barbaria'dır. Türkçedeki öteki kelimesi ise Latince ceterus'a (İng. the rest) yani geri kalana daha yakındır. (Nahya, 2011, 29) Öteki, İngilizce other kökünden gelmekte olup, "belirtilen ya da ima edilenden farklı olan, geleneğin dışında kalan" olarak tanımlanmaktadır. Öteki, biz tarafının bittiği yerde başlayan, biz'in dış sınırıdır. (Kaya Erdem, 2011, 48)

Nasıl ki ben kendisini tanımlayabilmek için öteki olana ihtiyaç duyuyorsa, toplumların kendilerini tanımlamaları da belirli farklılıkları olan toplumların varlıkları ile olur. $\mathrm{Bu}$ toplumların birbirleriyle karşılıklı ilişki ve etkileşimi olması gerekmektedir. Ötekilik olmadan kimlik olması düşünülemez. Aidiyet ya da kimlik, ötekilik ile tanımlanır. Bütün kimlikler farklılıklarıyla beraber vardır. (Bulut, 2010, 12) Her şey ötekisini bularak, öteki üzerinden kendisine değer biçer. Ben'in ben olabilmesi için öteki'ye ihtiyacı vardır. Bu nedenle ben ve öteki bir arada bulunur. Yani öteki olarak adlandırılanların varlığı kabul edilir. Ben olan öteki'yi her zaman yok etmek istese de öteki olmadan da kendi varlığını inşa edemez, bu nedenle de öteki olana daima ihtiyaç duyar. Ben'in kendisine ilişkin yaptığı her belirleme aynı zamanda ben olmayana dair bir olumsuzlama içermektedir.

Dünya ben/biz ile sen/öteki ayrımı ve bu ayrım arasındaki ilişki üzerine kuruludur. Ben/biz ilişkisi her durumda güç/iktidar konumunda olduğu için sen/öteki karşısında daha güçlü bir konuma sahip olması olağandır. (Sözen, 1999, 29)

Farklı uluslararası ilişkiler kuramları ve farklı felsefi modernite söylemleri incelendiğinde, bu kuramların ve söylemlerin dört farklı öteki' ye yaklaşım modelini içerdikleri görülmektedir. (Keyman, 2002, 19)

İlk olarak; Ampirik/Kültürel bir nesne olarak öteki, üzerine bilgi toplanması gereken ve bu bilgilerle açıklanabilecek bir nesne olarak görülmekte, ötekileştirme tam da bu noktada başlamaktadır. Amaç, hakkında sözde nesnel ve gerçeklere dayanan bilgi sağlayarak, öteki 
olanı açıklamaktır. İkincisi yaklaşım bir varlık/ varoluş olarak öteki' dir. Hem farklılı̆̆a bir varoluş durumu, bir varlık olarak yaklaşır, hem de öteki'yi modern benliğin yaratılmasına katkıda bulunan görünmeyen benlik olarak tanımlar. Üçüncü yaklaşım, söylemsel bir kurgu olarak öteki' dir. Bir nesne veya bir varlık değil; "söylemsel bir kurgu" olarak tanımlanmaktadır. Sonuncu yaklaşım ise farklılık olarak öteki' dir. Farklılı̆̆ın ilişkisel niteliğini, sömürgeci Batı ile sömürge Doğu arasındaki karşılıklı bağımlılık ilişkisini ortaya çıkarmaktadır. (Keyman, 2002, 19- 22)

Öteki olarak adlandırılanlar, ben'in yaratmış olduğu düzeni bozacak olanlar olarak görülmekte ve yok edilmesi gerekenler olarak düşünülmektedir. Ötekiler, yok edilmedikleri takdirde toplumdaki sorunların, başkaldırışların, suçların nedeni olarak gösterilirler. Öteki karşısında birleşen insanlarda da biz duygusu gelişir. Öteki kavramı son zamanlarda, tehdit içeren ve önlem alınması gereken bir unsur olarak tasarlanmaya başlanmıştır. Bu tasavvurun sonucunda bireyin kendisinden farklı gördüğü kişileri dışlama, yabancılaştırma, düşman haline getirmeyi tanımlama amacı ile ötekileştirme kavramı literatüre eklenmiştir.

Ötekileştirme, öteki olarak görülenlerin haklarını sınırlandırmak ya da yok etmek anlamina da gelmektedir. Ötekileştirilenler genellikle negatif, değersiz ya da radikal olarak resmedilmekte, çok nadir olumlu idealleştirme yapılmaktadır. (Kılıç, 2011, 148) Ötekileştirme yapılarak insan haklarına müdahale etmek, sınırlandırmak veya yok etmek için bireyler nesneleştirilir. Bir diğer deyişle bireyler, şeyleştirilir. Bireyler varlıkları yerine, ötekileştirici unsurları ile adlandırılırlar. Örneğin, bulunmuş olduğu etnik yapıdan dolayı ötekileştirilen bir birey, artık ismiyle değil, etnik kimliği ile tanımlanmaktadır. Etnik kimliğin yanı sıra, cinsiyetçi, dini, ableist vb. ötekileştirme türlerinde de birey aynı duruma maruz kalır.

Belirli bir grubun üyelerinin, salt bu gruba aidiyetleri nedeniyle başka bir grup tarafından farklı bir gözle görülmesi ve dolayısıyla olumsuzlanması, ötekileştirme olgusunun temelidir. Toplum ve bireylerin, diğer toplum ve bireylerden dişlama pratiği olarak da görülebilecek olan ötekileştirme kavramı, ötekileştirmenin temelinde yatan negatiflikten kaynaklanmaktadır. Farklı olanlar ile olan ilişkiler geniş bir yelpaze oluşturur. Bu ilişkiler iş birliği ve birlikte yaşama yönünde gelişebildiği gibi, dışlama, rekabet, yabancılık, düşmanlık gibi biçimlerde de olabilir. Buradan da denilebilir ki her ötekileştirmenin temelinde, kategorilendirme mevcuttur; ama her kategorilendirmenin sonucu ötekileştirme değildir. (Bezirgan Arar ve Bilgin, 2010, 3) Kategorilendirmenin ötekileştirici bir anlam ifade etmesi için, farklılıkları öne çıkararak ben merkezli yaklaşma, dışlama gibi pratikleri içerisinde barındırması gerekmektedir.

\section{Etnosentrik Ötekileştirme Bağlamında Çingenelerin Ötekileştirilmesi}

İnsanlığın başlangıcından itibaren kendini öteki üzerinden tanımlama biçimi zaman içerisinde pek çok ötekileştirme türünü de beraberinde getirmiştir. Çalışmanın ana konusunu oluşturan Çingenelerin ötekileştirilmesi, etnosentrik ötekileştirme içerisinde yer almaktadır. Bu nedenle, etnosentrik ötekileştirmenin neyi ifade ettiğini bilmek, önem arz etmektedir.

Etnosentrizm kavramı, toplumsal farklılıkların genel bir bakışı olarak görülmesinin yanı sıra, doğası nedeniyle nefretin diğer türlerinden farklıdır. Ayrıca, eğilimlerin ön plana çıktığı pozitif ve negatif duyguları içermektedir. (Poyraz, 2017, 168)

Etnosentrizm kelimesi, ilk olarak 1906'da William Graham Sumner tarafından tanımlanmıştır. Sumner, grup içi ve grup dışı terimleriyle birlikte etnosentrizme açıklık getirmiştir. (Bizumic, 2014, 3) Sumner'a göre;

Grubun içerisinde olanlara karşı barış, düzen, kanun, yönetim, endüstri vb. Hepsi gereklidir. Grubun dıştakilerle ve dış grup ile ilişkisi savaş ve yağma üzerinedir. Gruba karşı sadakat ve fedakârlık ön plandayken, grubun dışında olanlara karşı nefret duygusu ön plana çıkar. 
Etnosentrizmde iç grup her şeyin merkezidir ve diş gruba ilişkin anlamlandırılan her şey iç grubun yorumlamalarına dayanır (Sumner'dan akt. Özbek, 2004, sy.).

Bir diğer deyişle, etnosentrizmin kökeninde derin bir ayrımcılık yatmaktadır. Grup içinde olanlar merkeze yerleştirilirken, grubun dışında olanlara nefret duyularak merkezin dışarısına atılmaktadır. Çingeneler de etnosentrik ötekileştirmeye maruz kalan gruplardan birisini oluşturmaktadır. Etnosentrik ötekileştirmeye maruz kalan Çingenelerin tarih boyunca ne olduklarına dair adlandırmalar da yine öteki unsuru olarak gösterilebilecek ifadeler barındırmaktadır. Yani ötekileştirme dilde/söylemde başlamaktadır. Bu nedenle "Çingene" kelimesini etimolojik çerçevede incelemek gerekmektedir.

"Çingene" İngilizcede "gypsy" ya da "gipsy" olarak kullanılmaktadır. The Oxford sözlüğünde Çingeneler, geleneksel olarak yaşayan, seyahat eden kişiler olarak tanımlanmaktadır. Yine sözlükte Çingenelerin Hintçe veya Güney Asya'dan gelen bir dil kullandığı açılanmaktadır. Çingene kelimesinin bir diğer anlamı ise "göçebe ve özgür ruhlu" kişiler olarak ifade edilmektedir. (The Oxford Dictionary, ty.)

Çingene kavramının tanımlanmasında dahi göçebe olmalarına vurgu yapılmaktadır. Tarihsel bağlamda pek çok yere göç eden Çingeneler, gittikleri her yerde farklı ötekileştirmelere maruz kalmış, kalmaya da devam etmektedirler.

Avrupa sınırları içerisindeki en eski kültürel ötekilerden biri olan Çingenelere, millet değil, bir grup insan gözüyle bakılmaktadır. 19. yüzyılda ise Çingeneler "Avrupa' nın zencileri" olarak görülmektedir. (Blum-Reid, 2005, 2)

Hint asıllı oldukları düşünülen Çingeneler, M.Ö 242-642 yılları arasında Hindistan'ın Kuzey kısımlarına doğru göç etmişler, daha sonra da İran'a doğru gitmişler. Bazılarına göre Çingeneler, Dom olarak isimlendirilen Hintli müzisyen demircilerin ya da savaşçıların neslinden gelmektedir. M.Ö 642-900 yılları boyunca Hintli göçmenler, Orta Doğu'ya zorla götürülmüsslerdir. M.Ö 900 yılından sonra Hintliler, Bizans İmparatorluğu'na doğru ilerlemişlerdir. Hintlilerin bir kısmı, Bizans İmparatorluğu'na gelmeden önce, Ermenistan'a hareket ettiklerinden Ermenice ve Yunanca dillerinden çok etkilenmişlerdir. (Kyuchukov, 2007, 71-72) Kuzey Hindistan'dan göç eden Çingeneler, "Domlar" olarak adlandırılırken, göç etmelerinin ardından "Rom" ve "Lom" isimleriyle anılmışlardır. Özellikle Ermenistan civarında Çingeneler "Lom" olarak bilinmektedir. (İlhan ve Fırat, 2017, 266)

Göçebe bir topluluk olarak yaşayan Çingeneler, kendilerine özgü dinamiklere sahip olsalar da ulusal bağlamda Çingenelerin algılanışı, stereotipler, damgalanmalar ve ayrımcılıkla ilintilidir. (Özateşler, 2016, 16) Gitmiş oldukları neredeyse her ülkede, kendi kültürlerini, inanışlarını, yaşam biçimlerini sürdürmeye gayret etmişlerdir. Ancak etnosentrik ötekileştirmenin yanı sıra; dini ötekileştirmeye de maruz kalmışlardır. Bu nedenle Çingenelerin inanışlarıyla ilgili pek çok görüş de yer almaktadır.

Dini görüşler bir toplumun tanımlanmasında önemli bir rol oynamaktadır. Çingenelerin dini görüşleriyle ilgili olarak tarihsel bağlamda çeşitli görüşler hâkimken, iki düşünce öne çımaktadır. Birincisi Çingenelerin herhangi bir dininin olmadığı olsa da misafir olduğu halkların dinine uyum gösterdikleri; ikinci görüş ise zamanında Çingenelerin kilisesinin domuz yağından inşa edilmiş olduğu, bu kiliseyi de köpeklerin yemiş olduğu görüşüdür. Bu görüş Romanya ve Macaristan'da yaygındır. (Berger, 2000, 13-14) Bir diğer deyişle, Çingenelerin inançları üzerinden de ötekileştirme yapılmaktadır. Yaygın iki ötekileştirici görüşten birincisi; Çingenelerin tamamen inançsız olduğu düşüncesiyken, diğeri de Hristiyanlık gibi bir dine inansalar dahi Çingenelerin kiliselerinin farklı olduğu onların domuz yağından inşa edilen kiliseye sahip oldukları ifadesi inançlarını aşağılamak için kullanılan bir ifadedir. Bu düşünceden hareketle, Çingenelerin göç etmiş oldukları ülkelerde dini görüşlerini 
söylemek istememesi olağan karşılanmaktadır. Çingenelerin, ırksal bağlamda ötekileştirmeye uğramasının yanı sıra, dinsel inanışları sebebiyle de çeşitli ayrımcılıklara maruz kalmaları muhtemeldir.

Çingenelerin inançlarını belirtmemelerinin nedenini Bauman'ın azınlıklarla ilgili görüşleri üzerinden açıklamak mümkündür. Ona göre bu durum azınlıkların, yöneticileri hoşnut etme telaşına düşmeleri ile ilintilidir. Azınlıklar, bir başkaldırı ihtimalinin olmadığını kanıtlayarak yöneticilerin kendilerine güven duymalarını sağlamaktadır. $(2014,99)$ Çingeneler de toplumlarda azınlık kesimi oluşturduğundan gerek geçmişte, gerekse günümüzde hep çoğunluktakileri hoşnut etmeye ve başkaldırı ihtimalinin olmadığını kanıtlamaya gayret etmişlerdir. İnanışları konusunda yaşamış oldukları suskunluk, bu duruma örnek teşkil etmektedir.

Çingenelerin bu zamana kadar karşılaştığı en büyük sistematik ötekileştirme Nazi Almanya'sı döneminde yaşanmıştır. Maruz kaldıkları jenosit, bunun en büyük göstergesidir. Nazi Almanya'sı döneminde Auschwitz kentindeki toplama kamplarında mahkûm edilen Çingene sayısı başlangıçta 200 iken; daha sonra bu sayı 23.000'e ulaşmıştır. Getirilen kişi sayısı arttıkça yaşam koşulları daha da kötüleşmiştir. Bu durumdan dolayı kaçmaya çalışsalar da kamp kayıtlarına göre otuz iki Çingene esiri öldürülmüştür. 1943 yılının Temmuz ayından itibaren Çingene kampını çevreleyen dikenli tel çitlere yüksek elektrik voltajı uygulanmıs, ancak bu engel bile kaçma çabalarına son verememiştir. (Lewy, 2000, 152-158).

Nazi Almanya'sında Çingenelere yapılan travmatik olaylardan birisi de deneylerdir. Dr. Josef Mengele mahkûm edilen Çingeneler üzerinde deneyler yapmak için aktif rol oynamıştır. Özellikle ikizler üzerinde çalışmalar yapan Mengele, ikiz Çingeneleri saatlerce soğuk odalarda bekletip deneyler yapmıştır. (Lewy, 2000, 158) Gerek Çingenelerin mahkûm edilmesi, gerekse mahkûmiyet koşulları Çingenelerin ötekileştirilmesine verilebilecek örnekler arasındadır. Nazi Almanya'sında Çingenelerin yaşadığ mümkündür. Günümüzde de Çingenelere karşı ön yargı devam etmektedir.

\section{Korkoro Filminin Dekonstrüktif Okuması}

Çingenelerin ötekileştirilmesinin ele alındığı bu makalede örneklem olarak Tony Gatlif'in yönetmiş olduğu Korkoro filmi ele alınmıştır. Çalışmanın bu bölümünde Derrida'nın dekonstrüktif okumasına ilişkin açıklamaların yanı sıra, filmin konusu ve çözümlenmesi yer almaktadir.

\subsection{Filmin Künyesi ve Konusu}

Yönetmenliğini Tony Gatlif'in yaptığ1 "Korkoro" 2009 yapımı bir filmdir. Filmde İkinci Dünya Savaşı sırasında yerleşik yaşama geçmeye zorlanan bir Çingene ailesinin hayatı konu edinmektedir.

Korkoro kelimesinin anlamı da filmin içeriği üzerine ipuçları barındırmaktadır. Çingene dilinde kullanılan "Korkoro" kelimesinin Fransızca karşılığ1 "Liberté" Türkçede ise "Özgürlük" anlamina gelmektedir. (IMDB, ty)

Çingenelerin esmer tenli olması, renkli giyim tarzları, müziğe olan düşkünlükleri, dansları, göçebe yaşamdan kaynaklanan farklı meslekleri film boyunca da resmedilmiştir.

Filmde yer alan karakterlere bakılırsa, ana karakterlerden biri olan Theodore'yi, Marc Lavoine canlandırmaktadır. Theodore, Çingenelere yardım eden belediye görevlisi olarak rol almaktadır. Filmdeki ana karakterlerden Lundi' ye hayat veren ise Marie-José Croze'dur. Lundi, Çingenelere yardım eden öğretmen rolünde oynamaktadır. Filmin en önemli karakterlerinden 
biri olan Taloche'e, James Thiérrée canlandırmaktadır. Çingene rolünde oynayan Taloche, filmdeki pek çok altmetni de izleyici ile buluşturan karakter olarak görülmektedir. Filmin bir diğer önemli karakteri de P'tit Claude ya da Çingenelerin deyişiyle Çororo'yu canlandıran çocuk oyuncu Mathias Laliberté' dir. Kimsesiz bir çocuğu canlandıran Çororo, Çingenelerin ailesine katılmaya çalışan "gaco" (çingene olmayan) olarak adlandırılmaktadır. Çororo'nun, Çingenelerle birlikte yer aldığı pek çok sahne ben ve öteki düalizminin net bir şekilde görülmesini sağlamıştır. Karakterlerin derinlemesine tahlili, filmin çözümlendiği bölümde daha ayrıntılı bir şekilde ele alınacaktır.

\subsection{Derrida'nın Dekonstrüktif Yaklaşımı}

Bu araştırmada Derrida'nın, dekonstrüktif yaklaşımı benimsenmiştir. Buna uygun olarak filmin içerisinde yer alan hem dilsel, hem de görüntüsel metinler üzerinden filmde nasıl bir anlatı kurulduğu, bu anlatının kurulmasındaki bağlamın neler olduğu anlamlandırılmaya çalışılacaktır. Bu noktada tematik olarak filmdeki ötekiler, ötekileştirici ifadeler, etnosentrik ötekileştirme, gözetim, denetim gibi olgular incelenecek ve bu olguların filmin metninde ve göstergelerinde nasıl yansıtıldığı açıklanacaktır.

Bu araştırmada Derrida'nın yapısökümcü okuması aslında görünür ve bütün olan "Çingenelerin Ötekileştirildiği" savını parçalara ayırarak, film aracılığıyla gündelik yaşam pratiklerinde yansımasının bütünden daha güçlü etkiler taşıdığı belirtilmiştir. Bu yapısökümü gerçekleştirirken, filmin temel birimleri olan mekânlar, karakterler ve söylem üzerinden yola çıkılarak, gündelik hayattaki ötekileştirmenin görünmez olduğu fakat yapısökümcü bir okuma ile bunun görünür kılındığında aslında baştaki bütüncül genel ötekileştirme algısından daha güçlü ve derin bir ötekileştirme algısını oluşturduğu, sonucu ortaya çıkmaktadır. Filmden bir örnek üzerinden gidilecek olunursa, mülk edinmenin genel bir perspektifle bakıldığında olumlu algıya temas ettiğini söylemek mümkündür; fakat Çingenelerin yaşam tarzı ele alındığında bunun da bir ötekileştirme, yaşam tarzına karışma olarak ele alınması gerektiği ortaya konulmuştur. Bu noktadaki bütüncül yapı, mülk edinme iyi bir yaşam iken; yapısökümcü bir okuma ile parçadaki ötekileştirme göç etmesini engelleyerek, tutsak etme amacı, görünür kılınmıştır.

Metin çözümlemesi, “filmile yazın eleştirisinde kullanılan yaklaşımlardan yararlanılarak, anlam üretiminin gerisinde yatan mekanizmaları anlamak için iletişim araçlarının biçim ve yapısını sorgulayan bir çözümleme biçimi" (Mutlu, 2004, 210) olarak tanımlanmaktadır. Film bir metin gibi ele alınarak, dekonstrüktif okuma ile incelenmiştir. Bir metin gibi ele alınan film, bütünden parçalara doğru ayrılmış, bu da kimlik, iktidar temsilleri, tahakküm yöntemleri gibi üst başlıkların irdelenmesini gerekli kılmıştır. Üst başlıklardan alt başlıklara doğru gidildiğinde, Çingenelerin gözetim ve denetim üzerinden merkezin dışına itilerek, öteki konumunda yer alması, tahakküm altına alınması bağlamında bir okuma gerçekleştirilmiştir.

Ünlü sinema kuramcılarından Robert Stam'a göre “Metinsel analiz, filmin bir araç gibi onu sadece edebi seçkinci yazımdan değil; aynı zamanda da filmleri yalnızca eğlence olarak gören gazeteci eleştiriden de ayıran ciddi bir çalışmayı hak ettiğini varsayar" $(2014,196)$. Peter Brunette de konuyla ilgili olarak film analizlerinde, basılı bir metne uygulandığı gibi bir araç olarak yapısöküm okuma yapılabileceğini belirtmiştir (Akt. Güven ve Serarslan, 2018, 44). Bu bağlamda metinsel analiz, metni parçalara ayırması bakımından dekonstrüktif bir tavır ile hareket etmektedir.

Film, bir metin gibi okunmaya başlandığında, aynı zamanda içerisinde göstergeleri, söylemi de taşımaktadır. Dolayısıyla sinemadaki metin çözümleme eyleminin içerisine çok sayıda farklı kategorinin dâhil olması kaçınılmazdır. Buradan hareketle dekonstrüktif okuma gerçekleştirilirken Derrida'nın düşünceleri ekseninde ilerleme gerçekleştirilmiştir. 
Dekonstrüksiyon bir metnin açıkça ifade etmek istediği şey ile anlatılmak zorunda kalınan şey arasındaki gerilimleri, istemeden el verdiği çıkmazları, kırılma noktalarını dikkatle arayıp bulmak olarak tanımlanabilir. (Kaya Erdem, 2011, 219) Bir diğer ifadeyle dekonstrüksiyon, metinde ortaya konulmak zorunda olunan şeylerin, perde arkasına bakılarak asıl anlatılmak isteneni ortaya çıkarmaktır.

Derrida, kendisini dekonstrüktif okumaya iten şeyin genel teorik ve sistematik bir felsefenin, dekontrüktif strateji ile hazırlanmadığı takdirde metinsel bozulmaların daima aşırı veya ampirik deneylere, bazen de aynı anda klasik metafiziklere düşme riski taşıdığı inancından kaynaklandığını belirtmektedir. (Derrida, 1981, 68)

Dekonstrüksiyonu bir kavram olarak ele almak yerine onu bir metin gibi okuyan Derrida, her okuma sürecini bir kriz olarak düşünmektedir. Ona göre kriz çözülmeden okuma sona ermemektedir. Dekonstrüksiyon, devam eden krizi imlemeyen bir metin okuma stratejisidir. (Rutli, 2019, 24) Ele alınan bu çalışmada da film okuması Çingenelerin ötekileştirilme krizinin sona ermediğini ve Derrida' nın söylemiş olduğu gibi devam eden krizin okunmasına bir örnek teşkil etmektedir. Devam eden bu kriz filmde, mekânlar, karakterler, müzik gibi etmenler üzerinden incelenmiştir. Her değişen mekânın dekontrüktif okuması, aynı zamanda özneler arasındaki krizi de anlatmaktadır.

Derrida, "Yaşlı Avrupa, kendi özdeşliğini saptama üzerine olan bütün söylem ve karşı-söylem olasılıklarını tüketmiş gözüküyor" $(2011,30)$ diyerek, Batı metafiziğinin düalist yapısının sona erdiğini belirtmektedir. Dolayısıyla bu araştırma kapsamında filmde kullanılan dekontrüktif okuma aslında Batı metafiziğinin özcü bir ben ve öteki karşıtlığından ziyade; bütünü parçalara bölerek, sürekli krizin çeşitli mekân ve karakterler aracılığıyla kendini yeniden ürettiğini anlatma amacıyla kullanılmıştır.

Derrida, "Japon Dosta Bir Mektup" adlı yazısında dekonstrüksiyonun ne olmadı̆̆ını anlatmakta ve Fransızca'da açı ve tek bir anlamı olduğunu düşünmemek gerektiğini de vurgulamaktadır. $(2008,187)$ Diğer bir deyişle Derrida dekonstrüksiyon kavramının tek bir anlam içerecek şekilde anlatımını reddetmektedir. Buna ek olarak yapısökümün bir yöntembilim olarak ele alınamayacağını da belirtmektedir. $(2008,189)$

Mevcut varlığın açılımıyla ilgili olarak çizgisel bir şema bulunmakta, bahsi geçen çizgisellik şeması, düz veya dairesel olabilmektedir. Derrida, bu çizgisel tarih modelini reddeder. Çizgisel olmayan bir yazı ortaya koymak, farklı yazmak için tekrar tekrar okuma yapmak gerektiğini vurgulamıştır. (Derrida, 1997, 85-87) Bir diğer ifadeyle, metni okurken, düz anlamının dışında; derinlemesine okumalar yapılması gerektiğini, bu okumaların sonucunda da alt metinlerin ortaya çıkarılarak, metnin yeniden okunması gerektiğini vurgulamaktadır.

Derrida "Metin dışında bir şey yoktur" der. Gerçek olarak adlandırılan varlıklara yalnızca metin içerisinde erişebileceğimizi belirtir. (Derrida, 1997, 158) Ele alınan bu çalışmada da film çözümlemesi gerçekleştirilirken, ben ve öteki ayrımını, göstermek amacıyla film adeta bir metin gibi okunmuştur.

Ona göre, gösterilen ve gösteren ilişkisi keyfidir. Göstergenin, aynı zamanda gösteren olabileceğini düşünerek gösteren/gösterilen ayrımını sorunsallaştırmaktadır. (Evre, 2007, 13) Gösteren/gösterilen ilişkisi Derrida' ya göre iç içe geçmiştir. Gösteren olarak belirtilen şeylerin aynı zamanda gösterilen olabileceğini vurgulamakta ve böyle bir ayrımı sorunlu bulmaktadır.

Derridacı anlamda varlığın metafiziği, gösterge kavramıyla sarsılır; ayrıca nasıl konuşuyor, yazıyor ve okuyor olursak olalım, kelimelerin dile içkin olduğunu düşünmektedir. (Sözen, 2014, 53-54) Saussure'ün dilbilimde ortaya koymuş olduğu, gösteren, gösterge ifadelerini eleştiren Derrida, her metnin altının kazınması gerektiğini belirtmektedir. 
Yani açık anlatım olsa dahi derinlemesine okumalar yapılmalıdır.

"Dekonstrüksiyon hem tersyüz etmeyi, hem de müdahale etmeyi gerektirir. ...Dekonstrüksiyonu bir sistem, yöntem ve fikirler bünyesi olarak düşünmek, onun doğasını tahrif etmek gibi bir şeydir." (Sözen, 2014, 59) Bir diğer deyişle, dekonstrüktif okumalarda bir sinırlama ve kesin çizgiler yoktur.

Dekonstrüktif okuma temelde metnin yapısal dokusunu parçalara ayırarak ele aldığ metin içerisindeki kavramlardan hareket eder. Bu kavramlar içerisinde örtük olanı yerinden sökerek, ona yeni anlamlar kazandırmaktadır. (Güven ve Serarslan, 2018, 43) Ayrıca "Dekonstrüktif okuma dünyayı bir metin gibi görmektedir." (Sözen, 2014, 60) Bir diğer deyişle, edebiyat metinlerinden, sinemaya; haberlerden, mekân okumalarına kadar her şey metin olarak görülür. Bu nedenle, Korkoro filmindeki müzik kullanımından, renklere; sözcüklerden, mekânlara dair tüm öğeler bu bağlamda değerlendirilerek, incelemeye tabi tutulmuştur. Ayrıca filmin yönetmeni Tony Gatlif'in de düşünsel olarak yer aldığ 1 taraf, metni okurken göz önünde bulundurulması gereken noktalardan bir tanesidir. Bu durumdan hareketle yönetmenin düşünsel yapısı da okunacaktır.

Metin içerisinde yer alan ve okunması gereken metinler ile sinema filminin analizinin yapılması aynı sürece işaret etmektedir. Korkoro filmi özelinden gidildiğinde gerçek bir olaydan esinlenerek yapılan film, kurgusal bir anlatı ile bütünleşmiştir. Dolayısıyla metni yani filmi okurken, hikâyenin derinliğinde yatan Çingenelerin farklı coğrafyalarda yaşadığı ötekileştirme yaklaşımına işaret edilebilmektedir. Metnin bütünü, ötekileştirme ve gözetim başlığını verirken; derinlemesine inildiğinde hangi karakterlerin gözetime karşı özgürlüğü temsil ettiğini dekonstüktif bir anlayışla ortaya çıkarmak gerekmektedir. Film analiz edilirken, bu teknik ile ilerleyerek karakterler üzerinden de okuma mümkün olacaktır.

Dekonstrüktif okuma yapilırken, New Mexico Literacy Project (Nkana, 2010, 174175) adlı grubun tanımlamış olduğu sorular üzerinden okuma gerçekleştirilecektir. Grup, dekonstrüktif okuma yaparken sorulması gereken soruları şöyle sıralamıştır:

1-Bu kimin mesajıdır? Bu medya iletisini kim yaratmış ya da finanse etmiştir? Neden?

2-Hedef kitle kimdir? Hangi metin, imaj veya ses buna işaret etmektedir?

3-Bu iletinin düz anlamı nedir?

4-Bu iletinin altmetni nedir? Gizlenen ve söylenmeyen anlamlar konusunda ne düşünüyorsunuz?

5-Bu mesajların kazananı ve kaybedeni kimlerdir?

\subsubsection{Bu kimin mesajıdır? Bu medya iletisini kim yaratmış ya da finanse etmiştir? Neden?}

Etnosentrik ötekileştirme bağlamında Çingenelerin ötekileştirilmesinin ele alındığ çalışmada, örneklem olarak bir sinema filmi belirlenmiştir. Bu nedenle mesajı oluşturan da filmin yönetmenidir. Ele alınan Korkoro filminin yönetmeni Tony Gatlif'tir. Bu noktada Tony Gatlif'in bu medya iletisini neden yarattığını bulmak için, yönetmen üzerinden ekonomipolitik bir okuma gerçekleştirmek zaruridir.

10 Eylül 1948 yılında Cezayir'de dünyaya gelen Tony Gatlif'in asıl ismi Michel Dehmani'dir. 1960'larda Cezayir'den Fransa'ya göç eden Gatlif, sinemaya okul yıllarında ilgi duymaya başlamıştır. Yönetmenlik dışında, senaryo yazarlığı, oyunculuk ve yapımcılık da yapmıştır. Filmlerinin genel temasını Çingeneler oluşturmaktadır. (Çakan, t.y.) Kendi kökleri 
de Çingenelerden gelen yönetmenin bu mesajı iletmesindeki neden, etnosentrize edenlere eleştirel bir mesaj vermektir. Batı metafizik düşünce geleneğinde logos merkeze Batılılar konulurken; merkezin dışında kalanlar, "öteki” olarak görülenler, periferiye itilmiştir.

\subsubsection{Hedef kitle kimdir? Hangi metin, imaj veya ses buna işaret etmektedir?}

Korkoro filminde, geçmişten günümüze "Avrupa'nın zencileri" olarak adlandırılan Çingenelerin ötekileştirilmesinin, görmezden gelinmesine karşılık; onların gerçeklerini, öz değerlerini yansıtmak amaçlanmıştır. Filmin hedef kitlesini yalnızca ötekileştirilenler (Çingeneler) değil, ötekileştirmeyi (Ben/Biz) yapanlar da oluşturmaktadır. Dahası, filmde Çingenelerin sesini duyurmak, tarihsel bağlamda yaşanılan etnosentrik ötekileştirmeyi göstermek misyonu da üstlenilmektedir.

\subsubsection{Bu iletinin düz anlamı nedir?}

Dekonstrüktif okuma yapılırken, cevaplanması gereken üçüncü soru, metinlerin düz anlamının verilmesidir. Film okumasının gerçekleştirildiği bu çalışmada iletiler; söylemler, mekânlar, renkler ve sesler tıpkı birer metin gibi okunmuştur. Düz ve yan anlamların bir arada gösterilmesi çalışmanın anlaşılırlığı açısından zaruridir. Bu nedenle dördüncü soru olan yan anlamın içerisinde hem düz anlam hem de yan anlam okumasının birlikte verilmesi uygun görülmüştür. Düz anlamın aslında içerisinde çeşitli çelişki ve çatışmaları barındırdığı bu durumun da ancak yan anlam okumaları ile karşılaştırılarak gösterilebileceği düşünülmektedir.

\subsubsection{Bu iletinin altmetni nedir? Gizlenen ve söylenmeyen anlamlar konusunda ne düşünüyorsunuz?}

Media New Literacy Project sorularından dördüncüsü, metinlerin alt okumasının gerçekleştirildiği bölümdür. Bu bölüm, söylenmeyen ya da gizlenen anlamların ortaya çıkarıldığı kısmı oluşturmaktadır.

Korkoro filmine bakıldığında, yerleşik düzeni temsil eden iktidarın, Çingene ailesini "terbiye etmek" için gösterdiği çaba görülmektedir. Buradaki düz anlam, Batı tipi bir modernleşmenin gereği olarak yerleşik yaşama geçilmesi şartıdır. Çingenelerin de "modernleşmek" için göçebe yaşamı terk etmesi ve yerleşik yaşama geçmesi onların yararına gibi gösterilmektedir. Oysa bu durumdaki altmetine bakılacak olursa, Çingenelerin kültürel kodlarının yok edilmeye çalışıldığı görülmektedir. Ayrıca, Çingenelerin yerleşik düzene geçirilme çabası, iktidarın kendisi için faydalı görmediği ve denetim altında tutamadığı Çingeneleri yerleşik yaşama geçirerek denetim altında tutma isteğinden kaynaklanmaktadır.

Oysa şu açıtır ki; Çingene kültüründe hareketsizlik, yerleşik yaşama zorlanmak, klasik anlamda "modern" yaşamın içerisinde yer almak aynı zamanda ölümle de eşdeğerdir. Fakat iktidar açısından bakıldığında ise Çingene ailesi, savaş sırasında başıboş gezen ve faydalanamadığı (örneğin savaş için kendisine eklemleyemediği, vergi alamadığı) bir yapıdadır. Bu durumdan dolayı yerleşik yaşama geçirilmesi zorunludur. Bu bağlamda bakıldığında, sürekli hareket halinde olan Çingene ailesinin gerek yaşadığı mimari yapı ve mekânlar, (onlar için bu çadırlar ve gözetimden uzak araziler, ormanlar olacaktır), hareket etmelerini sağlayan at arabası (onlar için özgürlüğü simgelemektedir), enstrümanları, dansları vb. birçok şey bu küçük Çingene ailesinin yaşamının olmazsa olmazlarındandır.

Bauman'ın, gözetim ve iktidar ilişkisini açıkladı̆̆ı, Ernest Gellner'ın bahçıvanlar ve yabani ot benzetmesi bu durum ile birebir örtüşmektedir. "Ne kadar iyi olursa olsun bahçenin kendini yeniden üretmesi konusunda bahçe tasarımına güvenmek olmaz" der. Yabani otlar sürekli gözetim gerektirir. "Moderniteyi yaratan iktidar bahçıvan modeli üzerine kuruludur." 
(Bauman, 1996, 67) Filmde de iktidarlar, yabani ot olarak görülen Çingeneleri gözetim altında tutmak için göçebe şekilde yaşamalarına izin vermemektedir.

Foucault iktidarların toplumu savunurken, ötekilere karşı kendilerini ya da ötekilerin başkaldırısına karşı egemenliklerini savunabileceklerini ve bunu uyruklaştırma içerisinde kalıcı kılabileceklerini düşünmektedir. $(2002,34)$ Filmde de iktidar olarak görülebilecek olan Fransız askerleri ve hükümeti, öteki olarak görülen Çingenelerin başkaldırılarına karşı çeşitli önlemler almaktadır. Bu önlemlerden en öne çıkanı da göçebeliği durdurma kararıdır. Bu durum yalnızca Çingenelerin yaşam tarzlarına müdahale etmek değil, aynı zamanda öteki olanı kontrol altında tutmanın da bir göstergesi olarak okunabilir.

Filmde öğretmen Matmazel Lundi'nin çocukların okula gelmelerine karşılık olarak yolladığ1 yiyecekler, Çingene aile tarafından eşit bir şekilde bölüşülmektedir. Buradaki düz anlamda Çingenelerin aç ve yardıma muhtaç bireyler gibi görülmesi vardır. Ancak altmetine bakıldığında Batılıların, Çingeneleri korkulacak, acınacak veya dışlanan bir varlıkmış gibi gösterilmesinin aksine; Çingenelerin aslında ne kadar paylaşımcı olduğu verilmektedir. Etnosentrik ötekileştirmenin eleştirel olarak gösterildiği filmde, Çingenelerin yaşamlarının ön yargıların ötesinde olduğunun önemli bir sahnesidir. Batılıların, Çingeneleri ötekileştirmek için sunmuş olduğu dişlayıcı pratiklerin dışında farklı bir bakış açısı getiren yönetmen, Batılıları eleştirmekte, Çingeneleri sunulmuş olan yargıların ötesinde göstermektedir.

Filmde mekânsal okumaları gerçekleştirmenin en önemli nedeni, içerisinde barındırdı̆̆ı diyalektiklikten kaynaklanmaktadır. Mekân toplumsal ilişkileri hem yansıtmakta, hem de etkilemektedir. Mevcut iktidarın yürüttüğü tahakküm ve hegemonyanın sürmesine, sağlamlaşmasına ve güçlenmesine katkı sağlayacak bir kullanım nesnesi olması anlamında veya tahakküm ve hegemonyanın yıpranmasına hatta çökmesine neden olabileceği için diyalektiktir. (Öztürk, 2012, 27-28) Çalışmada hem tablo şeklinde genel olarak mekânların düz anlam ve yan anlam okumaları verilmiş hem de metin içerisinde derinlemesine okuma gerçekleştirilmiştir.

\begin{tabular}{|l|l|l|}
\hline Mekân & Düz Anlam & Altmetin okunması \\
\hline Çadırlar & Evsiz Çingenelerin, çadırda yaşaması & $\begin{array}{l}\text { Çadırlar, Çingenelerin yaşam tarzlarını, } \\
\text { özgürlüklerini temsil eder. }\end{array}$ \\
\hline Orman & Doğa & $\begin{array}{l}\text { Batı tipi modernleşmeye karşı, taşsız } \\
\text { duvarsız özgür mekân }\end{array}$ \\
\hline Gökyüzü & Doğa & Özgürlüğün temsili \\
\hline $\begin{array}{l}\text { Toplama } \\
\text { Kampı }\end{array}$ & $\begin{array}{l}\text { Batı tipi modernleşmenin gerekliliği } \\
\text { olarak yerleşik yaşama zorlanan } \\
\text { Çingeneler }\end{array}$ & $\begin{array}{l}\text { Kamptaki teller, tutsak olanı; kapatılan } \\
\text { Çingeneler özgürlüğün yitimini } \\
\text { göstermektedir. }\end{array}$ \\
\hline $\begin{array}{l}\text { Çingenelere } \\
\text { verilen ev }\end{array}$ & Batı tipi modern yaşamın simgesi & Çingeneler için tutsaklığın mekânı \\
\hline
\end{tabular}

Filmin mekânlarına bakıldığında özgürlük söyleminin üretildiği yerleri vurgulamak için seçildiği görülmektedir. Öncelikle Çingene ailesinin evi olan çadırlardan başlamak gerekmektedir. Bachelard evi "gerçek bir kozmoz" $(2017,34)$ olarak nitelendirmektedir. Bu küçük Çingene ailesinin kozmosu ise çadırlarıdır. Çadırların düz anlamına bakılacak olursa, kalacak bir evi olmayan Çingenelerin çadırlarda yaşaması resmedilmektedir. 
Ancak altmetinsel okumada durum bambaşkadır. Çingeneler için çadırlar, mekânsal olarak barınabilecekleri bir alanı tanımlarken, aynı zamanda kültürlerine uygun olarak sürekli hareket halinde olmaya hazır, onlar gibi göçebe olan bir nesneyi de betimlemektedir. Dolayısıyla, filmde olduğu gibi çadırlarının ellerinden alınması ve yok edilmesi aynı zamanda onlar için mekânsal bir ötekileştirme olarak da okunabilir. Mekân üzerine olan iktidarın söylemi, yerleşik yaşama geçirme üzerinedir.

Lefebvre' ye göre “Egemenlik 'mekân' demektir. (...) Egemen iktidar, askeri olarak hâkim olduğu bir mekân üzerinde yayılır" (Lefebvre, 2015, 288). Orman her ne kadar düz anlamda doğayı temsil etse de filmdeki altanlamı bambaşkadır. Orman; kapatılmaya karşı özgürlüğü, modern yaşama karşı çingenelerin dostu olan doğayı betimlemektedir. Taloche karakterinin ormanda dilediğince koşması, ormanın tehlikeye karşı koruyucu, saklayıcı bir mekân işlevi görmesi oldukça önemlidir. Aynı zamanda Çingenelerin göç yollarını da oluşturmakla birlikte beslenebilecekleri bir mekân olarak da görünmektedir. Taloche'un ormandayken üzerini yapraklarla örtmesi ise ormanın saklayıcılık ve koruyuculuğuna yapılan bir gönderme olarak okunabilir.

Filmdeki bir diğer mekânise gökyüzüdür. Düzanlamda gökyüzü yine doğayı göstermektedir. Ancak altmetinsel okumada özgürlüğe yapılan vurgunun mekânsal yansımalarından biri olarak görülmektedir. Aynı zamanda ötekileştirme bağlamında bakıldığında yüzün yukarı dönük olması, yere bakılmaması fiziksel olarak da ötekileştirmeye karşı yapılan bir duruş olarak okunabilir.

Filmin diğer temel mekânlarından biri ise toplama kampıdır. Çingene ailesi burada iktidarın gözetimi ile karşılaşmıştır. Foucault'un hapishaneler ve gözetim için belirttiği "hiyerarşik gözetim" $(2015,256)$ burada toplama kamp1 olarak belirmektedir. Toplama kampında Taloche'un gözüktüğü sırada duyulan "Özgürlük. Özgür olmak istiyorum" sesi ile toplama kampının telleri birbiri ile karşıtlık oluşturmaktadır. Tekrar Foucault'a dönülecek olunursa "kamp, genel bir görülebilirlik etkisiyle hareket eden bir iktidarın diyagramıdır" (2015: 257) denilebilir. Kamptaki askerler, iktidarın eli, kolu, bedenidir. İktidarın mekânı, mimarisi ve yapısı ile tahakkümün hatırlatılması üzerine kuruludur.

Filmde mekânsal okumanın ardından söylemsel anlamda da düz anlam ve altmetin okuması gerçekleştirilmiştir. Mekânsal okumada olduğu gibi söylemsel okumada da tablo şeklinde ve ayrıntılı olarak okuma gerçekleştirilmiştir.

\begin{tabular}{|l|l|l|l|l|}
\hline Söyleyenler & Söylenenler & Söylemler & Düz anlatım & Altmetinsel okuma \\
\hline $\begin{array}{l}\text { Fransız } \\
\text { köylüler }\end{array}$ & Çingeneler & $\begin{array}{l}\text { "Pis suratlı } \\
\text { komşulara } \\
\text { ihtiyacımız yok." }\end{array}$ & $\begin{array}{l}\text { Çingenelerin } \\
\text { komşu olarak } \\
\text { istenmemesi }\end{array}$ & $\begin{array}{l}\text { Çingenelerin, fobik temsil } \\
\text { üzerinden ötekileştirilmesi. }\end{array}$ \\
\hline $\begin{array}{l}\text { Fransız köylü } \\
\text { çocuklar }\end{array}$ & Çingeneler & $\begin{array}{l}\text { "Çingeneler geri } \\
\text { döndü" }\end{array}$ & $\begin{array}{l}\text { Çingenelerin } \\
\text { köye } \\
\text { döndüğünün } \\
\text { haberinin } \\
\text { verilmesi }\end{array}$ & $\begin{array}{l}\text { Fobik temsil üzerinden } \\
\text { Çingenelerin korkulması } \\
\text { gereken bir varlık gibi } \\
\text { algılanması. }\end{array}$ \\
\hline $\begin{array}{l}\text { Fransız köylü } \\
\text { çocuklar }\end{array}$ & Çingeneler & $\begin{array}{l}\text { "Babam } \\
\text { Çingenelerin } \\
\text { çocuk kaçırdığını } \\
\text { söyler" }\end{array}$ & $\begin{array}{l}\text { Çocuklar } \\
\text { arasındaki } \\
\text { çekişme }\end{array}$ & $\begin{array}{l}\text { Çingenelerin korkulması ve } \\
\text { toplumdan uzaklaştırılması } \\
\text { gereken varlık olarak } \\
\text { görülmesi. }\end{array}$ \\
\hline
\end{tabular}




\begin{tabular}{|c|c|c|c|c|}
\hline Çingeneler & Çororo & “Beyazmış" & $\begin{array}{l}\text { Çocuğun } \\
\text { ten rengine } \\
\text { vurgu } \\
\text { yapilması. }\end{array}$ & $\begin{array}{l}\text { Fiziksel olarak kendini “öteki” } \\
\text { üzerinden tanımlama }\end{array}$ \\
\hline Çingeneler & Çororo & $\begin{array}{lr}\text { "Çororo } & \text { seni } \\
\text { seviyoruz } & \text { ama } \\
\text { bizden } & \text { biri } \\
\text { değilsin" } & \end{array}$ & $\begin{array}{l}\text { Çingene } \\
\text { olmamanın } \\
\text { ifadesi }\end{array}$ & $\begin{array}{l}\text { Kendini, öteki üzerinden } \\
\text { tanımlama. }\end{array}$ \\
\hline $\begin{array}{l}\text { Fransiz } \\
\text { askerler }\end{array}$ & $\begin{array}{l}\text { Lundi ve } \\
\text { Theodore }\end{array}$ & $\begin{array}{l}\text { "Çingenelere } \\
\text { yardım etmek de } \\
\text { en az Çingene } \\
\text { olmak kadar } \\
\text { suçtur." }\end{array}$ & $\begin{array}{l}\text { Çingenelere } \\
\text { yardım } \\
\text { edilmemesi } \\
\text { gerektiğinin } \\
\text { ifadesi. }\end{array}$ & $\begin{array}{l}\text { Makbul özne, "öteki" } \\
\text { olarak kabul edilenleri } \\
\text { ötekileştirmezse, makbul } \\
\text { olmaktan çıkıp ötekileştirmeye } \\
\text { maruz kalır. }\end{array}$ \\
\hline Çingeneler & $\begin{array}{l}\text { Fransiz } \\
\text { yetkili }\end{array}$ & $\begin{array}{l}\text { "Bu sizin } \\
\text { savaşınız! } \\
\text { Biz hiçbir } \\
\text { zaman savaş } \\
\text { başlatmadı!!" }\end{array}$ & $\begin{array}{l}\text { Çingenelerin } \\
\text { savaşa } \\
\text { katılmadığı }\end{array}$ & $\begin{array}{l}\text { Çingenelerin yaşam tarzı } \\
\text { olarak herhangi bir savaşta } \\
\text { taraf olarak yer almaması ve } \\
\text { kendilerini öteki üzerinden } \\
\text { tanımlaması. }\end{array}$ \\
\hline Fransız yetkili & Çingeneler & $\begin{array}{l}\text { "S a v a ş t a y } 1 \mathrm{z} \\
\text { durum çok ciddi" }\end{array}$ & $\begin{array}{l}\text { Savaştaki } \\
\text { olağanüstü } \\
\text { hal }\end{array}$ & $\begin{array}{l}\text { Çingenelerin göç etmesini } \\
\text { engelleyerek denetim altına } \\
\text { almak }\end{array}$ \\
\hline Talosche & İktidarlar & $\begin{array}{l}\text { “Suyu özgür } \\
\text { bırakın” }\end{array}$ & $\begin{array}{l}\text { Musluğun } \\
\text { açık } \\
\text { bırakılması }\end{array}$ & $\begin{array}{l}\text { Çingenelerin, özgür yaşama } \\
\text { isteklerin su üzerinden temsili }\end{array}$ \\
\hline
\end{tabular}

Filmin söylemlerine bakıldığında, yüzeyselden derine doğru gidilirken söylemin düz anlamının farklılaşarak altmetin okumasına bir olanak yarattığı gözükmektedir. Bazı Fransız köylülerinin "Pis suratlı komşulara ihtiyacımız yok." diye bağırması düz anlamıyla sadece komşu olarak istenmeyen bir takım kişilere vurgu olmasının yanı sıra, altmetine bakıldığında Çingenelerin fobik temsil üzerinden ötekileştirildiği salık verilmektedir.

Yerleşik yaşayan köylüler tarafından Çingeneler, korkulan, "çocuk kaçıran" özneler olarak betimlenmiştir. Bu durumu ifade eden diğer söylem de "Çingeneler geri döndü!" diye köye doğru koşturan açık tenli kız çocuğudur. Bu sahne sıradan, tüm bağlamından kopararak yüzeysel olarak ele alındığında düz anlatım Çingeneleri köye geri döndüğünü haber veren bir anlam taşımaktadır; fakat altmetine bakıldığında yine Çingeneler, bazı Fransız köylüleri tarafından fobik bir temsil üzerinden korkulması gereken varlıklarmış gibi algılanmaktadır. Korku, aynı zamanda saldırganlığ 1 da beraberinde getirmektedir. Metnin derinine inildiğinde bu korkunun, saldırıya, köyden Çingeneleri atmak istemeye kadar uzanacağı görülmüştür. Fobik temsil, korkuyu besleyen bir işlev gördüğü için düşman yaratarak kendisini devam ettirmeye çalışan köylüleri ortaya çıkarmıştır.

Filmde çocukların aralarında konuştukları söylemler de Çingenelerin ötekileştirilmesini eleştirel bağlamda anlatan önemli sahnelerden birisini oluşturmaktadır. Fransız köylü çocuğunun, "Babam Çingenelerin çocuk kaçırdığını söyler." sözü düz anlamıyla her ne kadar çocuklar arasındaki çekişmeyi gösterir gibi görünse de altmetinsel bir okuma yapıldığında çocukluktan itibaren öğretilen ben ve öteki düalizmi göze çarpmaktadır. Küçüklükten başlayarak, kendini "öteki" üzerinden tanımlayan bireyler, korkulması ve ötekileştirilmesi gereken kişileri Çingeneler olarak belirlemişlerdir.

Çingenelerin Çororo'yu gördükleri ilk andan itibaren rengine vurgu yapmaları bireyin 
kendisini öteki üzerinden tanımlamasına örnek teşkil etmektedir. “Beyazmış!" söylemi düz anlamıla ten rengine vurgu gibi görülse de aslında kendilerinin çocuktan daha siyah olduğunu belirtmeleri için kullanılmıştır. Ötekileştirmenin temelinde yatan kendini öteki üzerinden tanımlama, bu sahnede açık bir şekilde görülmektedir.

Filmde ben ve öteki ayrımının net bir şekilde görüldüğ ü bir diğer söylem, Çingenelerin, Çororo'ya söylemiş olduğu "Seni seviyoruz ama bizden değilsin." söylemidir. Düz anlamda "bizden değilsin" söylemi Çingene olmamanın ifadesi olsa da yan anlamda, ben/biz olanın kendini öteki/ötekiler üzerinden tanımlamasıdır.

Bauman, biz ve onlar ayrımını sosyolojik bağlamda şöyle değerlendirmektedir: “ ‘Onların' olan 'bizim' olmaz ve 'onlar' 'biz' değildir; 'biz' ve 'onlar' ancak birlikte karşılıklı çatışma içinde anlaşılabilir" (2014, 78). Filmde de "Sen bizden değilsin" söylemi Bauman'ın onlar, bizim ayrımını gösterir niteliktedir.

Filmde Çingenelere yardım eden karakterlerden Lundi ve Theodore'nin tutuklandıkları sahne de derinlemesine okuma gerektirmektedir. Nazi askerlerinin bu iki karaktere hitaben "Çingenelere yardım etmek de en az Çingene olmak kadar suçtur." söylemi düz anlamda Çingenelere yardım edilmemesi gerektiğidir. Altmetinsel okumada ise, iktidar tarafından öteki olarak görülen kişilerin ötekileştirilmesi gerektiği, aksi takdirde ötekileştirme taraftarı olmayan kişilerin de onlardan biri olarak sayılacağı görülmektedir. Bir diğer deyişle, makbul özne, öteki olarak kabul edilenleri ötekileştirmezse, makbul olmaktan çıkıp ötekileştirilir. Askerlerin Lundi ve Theodore' yi gözaltına alması, ötekileşmenin politik bağlamdaki boyutu olarak da belirtilebilir. Lundi'nin direnişçilere yardım ettiğini haber alan iktidar, fiziksel işkence yoluyla onu "terbiye etmeye" çalışmaktadır. Bu iktidarın cezalandırma, tahakküm altına alma yöntemlerinden biridir ve kökeni oldukça eskiye dayanmaktadır.

Ben ve öteki düalizminin en net şekilde görüldüğü bir diğer söylem de "Bu sizin savaşınız. Biz hiçbir zaman savaş başlatmadık!" söylemidir. Düz anlamıyla Çingenelerin savaşa katılmadığı salık verilse de altmetinsel olarak, Avrupa' da o dönemde süren bir savaşın parçası olmadıkları ve herhangi bir yere aidiyetleri bulunmadığından kendilerini o savaş içerisine de dahil etmemeleridir. Çünkü bulundukları topraklar onlara ait değildir; sadece gelip geçtikleri yerlerden biridir. Yani, Avrupalıların aksine savaşmaya değer bir mülkleri veya toprakları yoktur. Ayrıca, onların zaten halihazırda varlıksal bir savaşı vardır. Varlıksal savaştan kasıt, kendi yaşam tarzlarına uygun bir yaşam biçimini kabul ettirme isteğidir.

Göçebe bir topluluk olarak yaşayan Çingenelerin göç etmesini engellemek için "Savaştayız, durum çok ciddi" söylemi ise, düz anlamıyla olağanüstü hali gösterse de altmetinsel okumada Çingenelerin iktidar olarak görülen Fransız yetkililerin tahakkümü altına girmelerini kolaylaştırma amacı taşımaktadır. Öteki olarak görülen Çingeneler, ne kadar iktidarın gözünün önünde olursa, o denli denetim de kuvvetli olacaktır. Ancak Çingenelerin yaşamış oldukları ormanlar, çadırlar ve de sürekli konar-göçer şekilde hareket etmeleri, iktidarların asla kabul etmeyeceği bir durumdur. Çünkü mekânsal bir gözetimin yokluğu iktidarın tahakkümünün de zayıflamasına neden olacaktır.

Filmdeki ana karakterlerden biri olan Taloche'un belediye başkanının evinde suları açması ve "suyu özgür bırakın" söylemi düz anlamıla meczup bir karakter olarak görülen bu karakterin, musluğu açık bırakıp suyla oynaması gibi görülse de altmetinsel olarak yerleşik yaşamın esaretine karşı çıkan bir söylemin ifadesidir. İktidar, yerleşik yaşamı öğütlese bile Çingeneler için özgürlük, çadırlar, ormanlar, akarsulardır. Bir diğer altanlam olarak ise musluk Batı tipi modernleşmenin bir öğesi olarak kendisini göstermektedir. Çingenelerde ise su, doğadaki kaynağında özgürdür. Filmde Çingenelerin özgürlüğü ile doğanın özgürlüğü birlikte temsil edilmiştir. 
Filme genel bağlamda düz anlatım olarak bakıldığında, Çingenelerin Batı tipi modernleşmeye uygun hale getirilmeye çalışıldığ1 görülmektedir. Oysa altmetinsel okumada Çingeneler, gerek tarihsel, gerekse günümüz bağlamında özgürlüklerini sürdürmek istemektedirler. Buradaki özgürlük herhangi bir iktidarın tahakkümü altına girmeksizin yaşamlarını sürdürme isteğidir. Bu durum film boyunca izleyiciye gösterilmektedir.

\subsubsection{Bu mesajın kazananı ve kaybedeni kimlerdir?}

Yönetmen Tony Gatlif, Çingenelerin ötekileştirilmesine eleştirel bağlamda yaklaşmaktadır. Media New Literacy Project'in beşinci sorusuna bakıldığında mesajın kazananı Çingenelerdir. Her ne kadar filmin sonunda Çingene ailesi toplama kampına kapatılmış, önemli karakterlerden biri olan Taloche öldürülmüş, çadırlar boş kalmış olsa da ateşin yanmaya devam edip dumanın çıkması Çingenelerin günümüzde de yaşamaya devam ettiklerini göstermektedir.

Filmin sonunda çalan şarkının sözlerine bakılacak olursa; "Neden burada olmadı̆̆ımızı merak eden olursa, 1şıktan ve gökyüzünden sürüldügüumüzü anlat." sözleri de Çingenelerin sırf yaşam tarzları yüzünden ötekileştirildiklerinin gösterildiği sahnedir. Mesajın kaybedeni ise Batı düalist epistemolojiyi savunanlardır. Yönetmenin eleştirel bakış açısı böylelikle yerini bulmuştur.

\section{Sonuç}

İnsanlığın varoluşundan bu yana kendini tanımlama biçimi olarak öteki olana daima ihtiyaç duyulmuş, bireyler, kendilerini tanımlarken, karşısındakilere göre ne olup ne olmadığına karar vermiştir. Batı metafizik düşünce geleneğindeki ikircikli yapı, geçmişten günümüze kendisini göstermektedir. Merkeze konulan bireyler ben/biz olarak adlandırılırken; merkezin dışında olup periferiye itilenler öteki/ötekiler olarak adlandırılmaktadır. Merkezin dışına itilip, ötekileştirilenlerdenbirideÇingenelerdir.Ötekileştirmetürlerindenetnosentrikötekileştirmeye uğrayan Çingeneler, çalışmada da ele alındığı gibi tarih boyunca dışlanmışlardır. Özellikle göçebe bir topluluk olmalarından dolayı, gerek koyu tenleri, gerekse yaşam tarzları nedeniyle pek çok toplum tarafından ötekileştirilmişlerdir. Özellikle Nazi Almanya'sında Çingenelerin yaşamış olduğu travmatik olaylar, etnosentrik ötekileştirmenin bariz bir şekilde görüldüğü dönemdir.

Filmde ortaya çıkan bir diğer sonuç ise Çingene ailesinin göçebe yaşamının, yerleşik sistemi yapısöküme uğratmasıdır. Hareket halindeki bu ailenin varlığı bir bütün olarak görülen yapı içerisinde bir gedik olarak görülmüş, bundan dolayı da denetim altına almak istenmiştir.

Araştırma çerçevesinde, etnosentrik ötekileşme bağlamında Korkoro filmi ele alınmıştır. Çingenelerin farklı coğrafyalarda maruz kaldıkları ötekileştirme pratikleri, filmde temsiller, diyaloglar ve gerçek bir hikâyeden alınmasının olay örgüsü ile işlendiği görülmüştür. Çingene dilinde "özgürlük" anlamına gelen "korkoro" kelimesi filmin adından da anlaşılacağı üzere, Çingenelerin özgürlük uğruna vermiş oldukları yaşam mücadelesini anlatmaktadır. Ancak özgürlüklerinden alıkonulan Çingene ailesi, film boyunca anlatılsa da filmin sonunda Talosche'un öldürülüp, ailenin tutuklanması ile Çingenelerin kazanan tarafta olduklarını göstermektedir. Çünkü filmin sonundaki "kalanlara bol şans" ifadesi ile at arabasının gıcırtısı göçün son bulmadığını, Çingenelerin de yaşam tarzlarından vazgeçmediklerini gösteren önemli bir altmetindir. Gündelik hayattaki gerilim devam edecektir. Dolayısıyla filmin sonu bir "son" değildir ve devinime işaret eden bir bitiş söz konusudur.

Film ötekileştirme bağlamında değerlendirilip, dekonstrüktif bir okuma gerçekleştirilmesinin ardından elde edilen sonuçlarda görülmüştür ki sinema ötekileştirmenin ortadan kaldırılması için önemli bir araçsal fırsat sunmaktadır. Tarihsel bir bilgi üzerinden 
inşa edilen Korkoro, aynı zamanda toplumun belli bir kesiminin gündelik hayatta öteki olarak gördüğü toplumsal gruplara yönelik bu algının değişmesi için de önemli bir rol üstlenmektedir. Ötekileştirme sorununu temel alan filmlerin, sadece öteki olarak görülen toplumsal gruba ait olan yönetmenler tarafından değil; aynı zamanda ben/biz ya da Batı metafiziğine göre Logos merkez olarak görülen toplumsal gruba ait yönetmenler tarafından da yapılması ihtiyacını ortaya çıkarmaktadır. Böylece sinemanın toplumsal işlevi daha fazla belirginleşecektir.

Bu çalışma kapsamında, genel olarak özcü bir yaklaşımla ele alınan ötekileştirme algısı ve pratikleri dekonstrüktif bir okuma ile parçalara ayrılmıştır. Buradan çıkan sonuç ise parçalardaki, yani gündelik hayattaki ötekileştirme eyleminin bütünde görünenden daha fazla etkili olduğu ve olumsuz sonuçlarının ortaya çıktığ1 görülmüştür. Korkoro filmi bağlamında ele alındığında mekân, karakterler, söylem gibi filmsel öğeler yoluyla ötekileştirmenin gündelik hayatta nasıl yansıma bulduğu açıklanmıştır. Film, gündelik yaşamda "görünmez" olan ötekileştirmeyi görünür kilmıştır.

\section{Kaynakça}

AA.com.tr (2018). https://www.aa.com.tr/tr/dunya/macar-bakan-siginmacilarinentegrasyonunu-cingenelere-benzetti-/1103042 (Erişim tarihi: 28.11.2019)

Bachelard, G. (2017). Mekânın Poetikası. (Çev. A. Tümertekin) İstanbul: İthaki Yayınları.

Bauman, Z., \& Atakay, K. (1996). Yasa koyucular ile yorumcular: modernite, postmodernite ve entelektüeller üzerine. Metis.

Bauman, Z. (2014). Sosyolojik Düşünmek. (Çev. A. Yılmaz) ePub düzenleme: Meritokrasi. İstanbul: Ayrıntı Yayınları.

Berger, H., (2000). Çingene mitolojisi. Ankara: Ayraç Yayınları.

Bezirgan Arar, Y. Bilgin, N. (2010). Gazetelerde ötekileştirme pratikleri Türk basını üzerine bir inceleme. İletişim Kuram ve Araştırma Dergisi. Sayı:30

Bizumic, B. (2014). Who Coined the Concept of Ethnocentrism? A Brief Report. Journal of Social and Political Psychology. V.211

Blum-Reid, S. E. (2005). The Elusive Search for Nora Luca: Tony Gatlif's Adventures in Gypsy Land. Portal Journal of Multidisciplinary International Studies, 2(2).

Bulut, Y. (2010). Oryantalizmin Kısa Tarihi. İstanbul: Küre Yayınları.

CNNTURK.com (2019) https://www.cnnturk.com/spor/ibrahimovicin-heykeline-irkcisaldiri (Erişim tarihi: 28.11.2019)

Çakan, G. (t.y) Tony Gatlif. (Çevrimiçi: https:/ / www.bagimsizsinema.com/tony-gatlif.html ) 22.04.2019

Derrida, J. (1981) Positions. (Trans. A. Bass) Chicago: University of Chicago Press.

Derrida, J. (1997) Of Grammatology. Baltimore and Londo: The Johns Hopkins University Press.

Derrida, J. (2008). Japon Bir Dosta Mektup. (Çev.M. Atıcı-M. Omay). Toplumbilim Dergisi (10). 187-190.

Derrida, J. (2011) Öteki Hedef (Başka Baş). (Çev: M. Başaran) İstanbul: Bağlam Yayıncılık.

Evre, B. (2007). Bir Düşünüş Biçimi Olarak Postmodernizm ve Temel Parametreleri. Akdeniz 
University Faculty of Economics \& Administrative Sciences Faculty Journal/Akdeniz Universitesi Iktisadi ve Idari Bilimler Fakultesi Dergisi. 7(13).

Foucault, M. (2002). Toplumu Savunmak Gerekir. (Çev. Ş. Aktaş)İstanbul: Yapıkredi Yayinlar1.

Foucault, M. (2015). Hapishanenin Doğuşu. (Çev. M. A. Kılıçbay) İstanbul: İmge Kitabevi.

Gatlif, T. (Yapımc1), \& Gatlif, T. (Yönetmen). (2010). Korkoro [Sinema Filmi]. Fransa: Lorber Films.

Güngör, N. (2016). İletişim Kuramlar ve Yaklaşımlar. Ankara: Siyasal Kitabevi.

Güven, Z. C., \& Serarslan, M. (2018). M. Butterfly Filminin Yapı Sökümcü Analizi.

SineFilozofi. 3(6). 39-56. DOI: 10.31122/ sinefilozofi.358193

IMDB.com (ty.) https://www.imdb.com/title/tt1495823/releaseinfo?ref =tt dt dt\#akas. Erişim tarihi: 12.09.2019

Hegel, G. W. F. (1986). Tinin Görüngübilimi. (Çev. A. Yardımlı) İstanbul: İdea Yayınevi. İlhan, S. F, M. (2017). Bir İnşa Süreci Olarak Çingenelik: Kuramsal Bir Çözümleme. Firat Üniversitesi Sosyal Bilimler Dergisi. 27(2). s 265-276.

Kaya Erdem, B. (2011). Doğu- Batı ikilemi Bağlamında El Cezire. İstanbul: Vadi Yayınları.

Keyman, E. F.(2002) Globalleşme, Oryantalizm ve Öteki sorunu: 11 Eylül sonrası Dünya ve Adalet. Doğu Batı dergisi. V:20, s. 11-32.

Kılıç, D. (Mart 2011). Bir Ötekileştirme Pratiği Olarak Basında Eşcinselliğin Sunumu Hürriyet ve Sabah (2008-2009). Gümüşhane Üniversitesi İletişim Fakültesi Elektronik Dergisi.

Kyuchukov, Hristo. (2007). "Bulgar ve Türk Müslüman Romanlaree $1 n$ Tarihi, Kültürü ve Dili". Yeryüzünün Yabancıları: Çingeneler. (Kolukırık, S. Ed.) İstanbul: Simurg Yayınları. ss.71-85.

Lefebvre, H. (2015). Mekânın Üretimi. (Çev. I. Ergüden). İstanbul: Sel Yayıncılık.

Lewy, G. (2000). The Nazi persecution of the Gypsies. Oxford University Press.

Mutlu, E. (2004). İletişim Sözlüğü. Ankara: Bilim ve Sanat Yayınları.

Nahya, N. ( 2011). İmgeler ve Otekileștirme: Cadılar, Yerliler, Avrupalılar. Atılım Sosyal Bilimler Dergisi. V:1. s.29

Nkana, S. (2010). Media Literacy Education: A Case Study of the New Mexico Media Literacy Project. Andrews University.

Oxford Dictionary. (t.y.) Gypsy. (Çevrimiçi: https://en.oxforddictionaries.com/definition/ gypsy) Erişim tarihi: 05.03.2019

Özateşler, G (2016). Çingene. Türkiye'de Yaftalama ve Dışlayıcı Şiddetin Toplumsal Dinamiği. İstanbul: Koç Üniversitesi Yayınları.

Özbek, M. F. (2004). Geleneksel Toplumlar ve Güven Bağlamında Etnosentrik Eğilim İlişkisi. (Çevrimiçi: http:/ / www.acarindex.com/dosyalar/makale/acarindex-1423868414. pdf) 19.04.2019

Öztürk, S. (2012). Mekân ve İktidar. Filmlerle İletişim Mekânlarının Altpolitikası. Ankara: Phoenix Yayınları. 
Poyraz, Ö. O. (2017). Etnosentrik Eğilimlerin Tüketici Davranışları Üzerine1 Etkisi: Azerbaycan ve Türkiye Karşılaştırması. Tüketici ve Tüketim Araştırmaları Dergisi= Journal of Consumer and Consumption Research. 9(2). 163-187.

Rutli, E.E. (2019) Yapısöküm ve Hakikat. Düşünbil Dergisi. 75. 22-26

Stam, R. (2014). Sinema Teorisine Giriş. (Çev. S. Salman, Ç. Asatekin) İstanbul: Ayrıntı Yayınları.

Sözen. E. (1999) Demir Kafesten Plastiğe Kimliklerimiz. İstanbul: Birey Yayınları.

Sözen. E. (2014) Söylem. Ankara: Birleşik Yayınları. 